\title{
LA RESISTENCIA FRANCESA A LA IDEA DE IMPERIO Y EL NACIMIENTO DE LA RAZÓN CATÓLICA DE ESTADO EN LA ÉPOCA DE RICHELIEU
}

\author{
THE FRENCH RESISTANCE TO THE EMPIRE IDEA AND \\ THE BIRTH OF THE CATHOLIC REASON OF STATE \\ AT THE TIME OF RICHELIEU
}

\author{
DOMINGO GONZÁLEZ HERNÁNDEZ \\ Universidad de Murcia
}

Recibido: 31/06/2019 Aceptado: 23/09/2019

\section{RESUMEN}

El Imperio ha sido, junto a la polis y el Estado, una de las grandes formas políticas de la historia occidental. Por su carácter misional y universalista, la idea de Imperio ha podido resultar problemática para el despliegue de las categorías propias al pensamiento político. Ninguna nación europea representa mejor que Francia la resistencia histórica e intelectual de la nueva forma política estatal frente al Imperio. A la sombra de la figura histórica de Richelieu, "fundador de la Europa moderna" en palabras de Hillaire Belloc, este trabajo explora los orígenes de la "razón católica de Estado" en las ruinas de la vieja Cristiandad.

Palabras clave: Imperio, Estado, Francia, Richelieu, razón de Estado. 


\section{ABSTRACT}

The Empire has been, together with the polis and the State, one of the great political forms of Western history. Due to its missionary and universalist nature, the idea of Empire has been problematic for the deployment of the categories proper to political thought. No European nation represents better than France the historical and intellectual resistance of the new state political form against the Empire. In the shadow of the historical figure of Richelieu, "founder of modern Europe" in the words of Hillaire Belloc, this work explores the origins of the "Catholic reason of state" in the ruins of the old Christianity.

Keywords: Empire, State, Franc, Richelieu, reason of State.

\section{FRANCIA, EL ANTI-IMPERIO}

Todo intento de construir una metafísica de las naciones está abocado al fracaso. Queda, sin embargo, la posibilidad de afirmar una definición de la íntima afinidad de las naciones con ciertas formas políticas a partir de su biografía histórica. En el caso de Francia, esta biografía no deja de plantearse históricamente a partir de una paradoja ciertamente desconcertante. Francia, la única nación que conserva el nombre de la tribu germánica que restauró el Imperio en Europa, ha sido la nación que más lo ha combatido. Según Von Lohausen,

De entre las potencias diversas que, una a una, fueron afrontando al Imperio de los Habsburgo, Francia se convirtió, cada vez más después de Luis XI, en el alma de la rebelión. Si bien la realeza francesa tenía los mismos orígenes que el Imperio Alemán, Francia era, por naturaleza, el anti-Imperio ${ }^{1}$.

El general austríaco Von Lohausen, uno de los grandes expertos en geopolítica del siglo XX, veterano de la II Guerra mundial a las órdenes de Rommel, insistía en sus análisis en que el sentido y la relación con el espacio, las necesidades y las pasiones de los pueblos, son motores de la historia del mundo que ninguna religión ni ideología pueden contrarrestar. Estas consideraciones pueden parecer chocantes si se aplican a la definición de la personalidad histórica de la nación francesa. ¿No ha sido acaso la patria que se ha derramado con genuina convicción (al menos en sus declaraciones) al servicio de una misión de 2007), 506.

1 Aymeric Chauprade, Géopolitique. Constantes et changements dans l'histoire (Paris: Ellipses, 
corte universalista, ya sea religiosa (las Cruzadas) o laica (los Derechos del Hombre)? ¿Y no ha sido también la nación que no ha dudado en servirse de esas "causas sagradas" (por retomar la expresión de Michael Burleigh ${ }^{2}$ ) para "profesar un egoísmo nacional feroz" y el "prejuicio de la Patria" (Maurras)? No será fácil encontrar a ningún otro pueblo europeo capaz de soportar mejor la dura carga de una simbiosis imposible entre el universalismo sagrado y el nacionalismo chovinista. De ahí que el análisis geopolítico alemán de autores como Von Lohausen sea tan valioso. Fueron estudiosos como él los que señalaron la llamativa libertad de Francia a la hora de escoger sus propias causas históricas en comparación con otras naciones, condicionadas por una geografía que limitaba su margen de acción en contraste con la desahogada posición geopolítica francesa:

Para los geopolitólogos alemanes, Francia, por el hecho de su situación geográfica, goza de una libertad de acción que no tuvieron jamás ni España, ni Italia, ni Alemania. Históricamente, estos tres países tuvieron que afrontar directamente a los sarracenos, los eslavos y los magiares. No podían obrar sino en relación a sus necesidades. Francia, sin embargo, tuvo la libertad de escoger realmente su política, de proclamar las Cruzadas y los Derechos del Hombre ${ }^{3}$.

En efecto, lejos de ver en ello una oposición insalvable, tal vez sea su privilegiada posición geoestratégica la que explique en buena medida la afición histórica de Francia a encabezar las grandes causas sagradas de cada época y a servirlas atendiendo en primer lugar a los intereses marcados por la política del individualismo nacional. En Francia, las misiones universales se declinan siempre en el binomio político amigo/enemigo.

La peculiar configuración histórica de la identidad francesa es una de las claves más relevantes para entender el éxito con el que afrontó políticamente a los Imperios sin dejar de defender, sobre el papel, las causas sagradas con que estos últimos justificaban la legitimidad de su hegemonía. La hija primogénita de la Iglesia fue la nación católica que combatió con más eficacia al Sacro Imperio Romano Germánico. Gracias al testimonio de Francia entendemos mejor la inextirpable dimensión política de las llamadas "guerras de religión". Ni siquiera en ese contexto histórico, de místico fervor en defensa de la fe, la dialéctica amigo/enemigo podía traducirse sin falsificación histórica en cualquier otra clase de binomio moral o religioso completamente cristalino. Ahí estaba Francia y la política de sus reyes para desmentirlo. Una vez más, Francia "elegía" su

2 Michael Burleigh, Causas sagradas (Madrid: Taurus, 2006).

3 Chauprade, Géopolitique, 508. 
política con plena libertad y lo hacía contra el Imperio y en nombre de la misma causa religiosa. Nunca el Imperio tuvo un enemigo más fiero, pues no solo frustraba sus expectativas de supremacía con la fuerza de sus ejércitos sino que lo hacía también con la autoridad de sus obispos y cardenales, así como de los incontables Papas afectos a los desvelos de su hija primogénita. Aunque separada muy pronto del destino imperial de Carlomagno, Francia conservó, no obstante, la marca genética y fundacional de una misión divina en competencia "mimética" con el Imperio. Es quizá uno de los rasgos más definitorios de su identidad.

¿Quién es el culpable del complejo francés de superioridad, de la Grandeur autoasumida de la fille aînée de l'Église? Los psicólogos hablan del síndrome del "niño emperador" para referirse a los niños que acaban por dominar a sus padres. Es una curiosa fórmula ya que, en el caso de Francia, el síndrome aquejó paradójicamente a la nación llamada a combatir al Imperio empujada por el privilegio de primogenitura de su filiación con la Iglesia. Y al igual que los psicólogos señalan la responsabilidad de la educación de los padres para comprender la formación del carácter de esos niños imperiales, también en nuestro caso debemos señalar a los padres de Francia (el Imperio de Carlomagno y la Iglesia Católica) como los principales responsables de una educación conducente a la afirmación de un orgullo nacional basado en la suprema legitimidad de una misión divina. "Los obispos hicieron a Francia como las abejas hacen la colmena", escribió Joseph de Maistre. Esta observación no carece de valor pero parece incluso demasiado restrictiva. Fue la Iglesia entera la que alimentó la vanidad religiosa de la nación francesa. Fue la Iglesia quien le dio forma, quien la cultivó sin dejar de excitar y glorificar con su educación los logros y conquistas de su hija predilecta.

\section{UN ESTADO CONTRA EL IMPERIO: RICHELIEU, FUNDADOR DE LA EUROPA MODERNA}

En este trabajo sostendremos que buena parte de las tensiones de la historia y la identidad de Francia se ajustan a la aporía de la forma política con la que ha querido servir a su misión universal. El Estado ha sido una herramienta particularista que ha determinado buena parte de las dinámicas históricas que explican la oposición francesa al Imperio. La victoria de Francia en el siglo XVII contra la hegemonía española fue también la victoria de la forma política estatal frente a la forma política imperial. 
¿Dónde situar las raíces históricas de esta encrucijada? El colombiano Nicolás Gómez Dávila escribió: "El Estado moderno es la transformación del aparato que la sociedad elaboró para su defensa en un organismo autónomo que la explota"4. Francia elaboró un aparato para su defensa. Y el arquitecto de ese aparato fue el Cardenal Richelieu. La clave para entender la génesis de ese aparato se encuentra, en plena sintonía con la tesis hobbesiana, en la guerra civil que desangraba a una Francia cada vez más dividida en facciones religiosas, políticas y sociales. Como recuerda Philippe Erlanger, biógrafo de Richelieu:

Nadie fue un creador más grande que Armand du Plessis. Cuando la tomó en mano, Francia no era solamente una nación a la deriva, la anarquía total la devoraba, su debilidad frente a las otras potencias la convertían en una especie de bien vacante, una entidad casi virtual. Nada parecía imposible: su desagregación, una república protestante del Midi, provincias que proclaman su independencia, otras que caen en manos de los Habsburgo, un fraccionamiento, una satelización, una decadencia similar a la de Italia ${ }^{5}$.

Es aquí donde aparece la idea y la política fundadora de Richelieu. La excepcionalidad política de la Francia destruida por las guerras de religión abría el horizonte histórico a la afirmación de nuevas posibilidades de definición política. Como escribe Dalmacio Negro:

En los momentos fundacionales de una unidad política -un importante locus clásico de la filosofía política prácticamente abandonado-, la situación es de suyo excepcional, siendo entonces esencial la decisión. Pues la excepción política nunca versa sobre algo objetivamente existente y determinable, sino que tiene el carácter de innovación de acuerdo con una idea rectora: es una decisión histórica, sobre el futuro, para hacer viable una posibilidad histórica. En ella se descartan otras posibles opciones, a favor de lo que se elige e impone ${ }^{6}$.

Erlanger lo expone a su manera elevando la dimensión histórica de la figura del Cardenal Richelieu a la condición de fundador de una nueva nación política tras la construcción del primer Estado moderno digno de tal nombre:

Luis XIII quería devolver su grandeza y cohesión a este reino perdido. Apoyado en él, Richelieu hizo mucho más: lo remodeló y, transformándolo por una revolución bastante similar a las del siglo XX, lo obligó a salir de su crisálida para convertirse en un país moderno ${ }^{7}$.

4 Nicolás Gómez Dávila, Escolios a un texto implícito (Bogotá: Villegas Editores, 2001), 256.

5 Philippe Erlanger, Richelieu (Paris: Perrin, 2006), 848-849.

6 Dalmacio Negro, Gobierno y Estado (Madrid: Marcial Pons 2002), 87-88.

7 Erlanger, Richelieu, 849. 
Francia era sin duda la alumna más aventajada de Europa para la edificación definitiva de la nueva forma política. Educada por la Iglesia, imitaba también al Imperio que renació con la dinastía franca. El nuevo modelo francés tomó muchos elementos tanto de una (la Iglesia) como del otro (el Imperio) y nadie mejor que un cardenal católico francés entregado al servicio de la monarquía capetiana para sentar las bases del nuevo orden político que asegurara la fortaleza del Estado recién inaugurado frente a los muchos enemigos interiores y la amenaza exterior imperial.

En la práctica, fueron decisivos para la consolidación y configuración de la estatalidad la acción y el trabajo de eclesiásticos como Cisneros, Wolsey, Richelieu o Mazzarino. [...] Todos ellos bajo la impronta del modo de pensamiento eclesiástico aún dominante, que determinaba las actitudes generales. El resultado fue que el Estado, (...), imitó y tomó de ella (la Iglesia) mucho más que las potestades: por ejemplo, la idea secularizada de cuerpo político derivada del concepto teológico del cuerpo místico en el que el individuo ontológico se convierte en individuo social, o la idea de jerarquía y de una administración burocrática en gran escala, y, en el trasfondo de todo ello, como impulsora y justificadora de su actividad, la citada idea dinámica de misión, aplicada ahora a la seguridad temporal ${ }^{8}$.

En su biografía del Cardenal, Hillaire Belloc bautiza a Richelieu nada menos que como "fundador de la Europa moderna".

Consecuencia de ello, por último, y sobre todo, fue la creación, en el centro de Europa, de una nueva nación moderna, altamente organizada y sometida a un fuerte centralismo monárquico, que, alcanzando rápidamente las cimas del genio creador tanto en literatura, como en las artes, como en la ciencia militar, había de constituir un modelo que sirviera de ejemplo al nuevo ideal nacionalista. Esta nueva nación organizada era Francia; y el hombre que llevara a cabo todo esto fue Richelieu. Él fue quien, subordinándolo todo a la monarquía que servía (y, por tanto, a la nación), hubo de consolarlo todo bajo la autoridad de la corona. [...] Él fue quien, por obra y gracia de su sola voluntad, logró consolidar el siglo XVII, y con él, aunque involuntariamente, la Europa de ayer. Obra suya es la Europa moderna ${ }^{10}$.

Es necesario interpretar la obra del nuevo cardenal-ministro (o del ministrocardenal, para ser más exactos con su ejecutoria histórica) en la óptica de la

8 Dalmacio Negro, Lo que Europa debe al cristianismo (Madrid: Unión Editorial, 2007), 319.

9 Es el título del primer capítulo del libro de Hilaire Belloc sobre Richelieu que se cita a continuación.

10 Hilaire Belloc, Richelieu (Barcelona: Editorial Juventud, 1937), 16. 
batalla teórica entre los derechos de la religión y los de la política. Esta batalla de largo alcance se ventilaba con el telón de fondo de las guerras de religión que sacudieron el viejo continente, y solo alcanzaron una solución tras el éxito político de la obra de Richelieu al frente del aparato estatal por él construido para servir a la monarquía francesa. Según Marcel Gauchet, la historia de las relaciones entre lo político y lo religioso comienza con milenios de colonización religiosa de la política, es decir milenios de "ocupación" religiosa de un terreno político acostumbrado a vivir en una minoría de edad tutelada por una mentalidad arcaica de carácter mítico-sagrado ${ }^{11}$. No hay que olvidar que "lo político salió del seno de lo sagrado"12, como nos recuerda Dalmacio Negro. Con el advenimiento del cristianismo, "la religión de la salida de la religión", se instaura un nuevo marco de relaciones, en el que lo político comienza a conquistar su independencia. En la modernidad triunfante se invierten las tornas y asistimos, por el contrario, a la colonización política de la religión (las religiones políticas o seculares representan quizá el estadio más avanzado de este proceso). Hoy llegamos quizá a la colonización filosófico-universalista de lo político por la ideología humanitaria de la democracia religiosa y los derechos humanos, nueva forma de evangelio secular y antipolítico que reivindica sus fueros con fervor mesiánico.

Octavio Paz dejó apuntado que la política limita a un lado con la guerra y al otro con la filosofía. La filosofía representa, en efecto, la forma-límite de un universalismo que fue siempre el punto de mira de la forma política imperial (pagana o cristiana). Frente a ella, la forma estatal, de matriz particularista, se define por el límite y la frontera de la enemistad, formulada a partir de criterios políticos, y tendente a eliminar progresivamente residuos morales o religiosos.

¿Qué representa la obra de Richelieu en el esquema transhistórico de Gauchet? En la tensión de la doble condición presente en la figura de Richelieu, ministro de una monarquía católica que acabó por difuminar a un príncipe de la Iglesia, se encarna, a modo de epítome, la transición moderna del polo religioso hacia el polo político. Su significación tal vez no se distinga (aparentemente) de otros cardenales con responsabilidades políticas similares, como Cisneros o Wolsey. Pero su relevancia decisiva en la construcción de la ratio status que iba a imponer la nueva potencia hegemónica de Europa le dota necesariamente de un protagonismo superior. Su labor debe interpretarse como un ejercicio declarado de afirmación de la primacía de la política (estatal) y de su lógica

11 Marcel Gauchet, El desencantamiento del mundo. Una historia politica de la religión (Madrid: Trotta, 2005).

12 Dalmacio Negro, Historia de las formas del Estado. Una introducción (Madrid: El Buey Mudo, 2010), 33 . 
(amigo/enemigo) por encima de las exigencias del guion religioso al que presuntamente debía atender un pastor de la Iglesia. Lo llamativo en este caso es que esta afirmación no se produce en el marco de las nuevas relaciones generadas por el pensamiento de matriz luterana con el que frecuentemente se asocia el predominio de la nueva hegemonía estatal, sino en el contexto de la monarquía católica más antigua de Europa ${ }^{13}$.

El nuevo Estado de Richelieu al servicio de Luis XIII se afirma hacia dentro contra los restos de la aristocracia feudal, contra la alta nobleza levantisca, y sobre todo, contra el "Estado dentro del Estado" representado por la minoría hugonote todavía infiltrada en el cuerpo político y social de la nación. En su decidida voluntad de luchar en el exterior contra el Imperio austro-español también despliega sus energías contra el enemigo interior, el partido devoto "colaboracionista" que, por razones esencialmente religiosas, se presentaba como aliado francés de la monarquía de los Habsburgo. El golpe fracasado contra Richelieu en la famosa "jornada de los incautos"14 arruinó las últimas esperanzas del partido devoto proespañol. Como resumió Ethienne Thuau en su estudio sobre la razón de Estado en la época de Richelieu, "en relación con la sociedad organizada, este autoritarismo traduce la voluntad de destruir las solidaridades infranacionales de la misma manera que destruye la solidaridad supranacional de la Res Publica christiana"15. El fortalecimiento del nuevo aparato estatal requería la completa sumisión al nuevo orden del viejo entramado estamental, así como de la élite hugonote disidente, en significativo contraste con la tolerante pastoral que Richelieu había sostenido en su época del obispado de Luçon. Pero ahora el cardenal no obraba como hombre de Iglesia sino como el ejecutor inflexible de la política que asegurara la nueva grandeza de la monarquía francesa. El éxito del ministro de Luis XIII es inseparable del nuevo orden europeo que sucederá a su muerte y que difícilmente puede desvincularse de su obra. El Ius Publicum Europaeum consagrado en el tratado de Westfalia fue, en el fondo, un Ius Publicum Richelieuano.

13 Sin ir más lejos, François Huguenin incluye la figura del Cardenal en su estudio sobre las grandes figuras católicas de Francia. François Huguenin, Les grandes figures catholiques de France (Paris: Perrin, 2016).

14 Con el nombre de "jornada de los incautos" (journée des dupes) es conocido el fracasado golpe de Estado contra el cardenal Richelieu organizado por el partido devoto reunido en torno a la Reina Madre María de Médicis, quien fuera paradójicamente la primera impulsora de la carrera política de Armand du Plessis. En un inesperado giro de la situación, que hacía previsible la defenestración del cardenal, Luis XIII defendió a su ministro (y a su política) contra el criterio de su madre.

15 Etienne Thuau, Raison d'État et pensée politique à l'époque de Richelieu (Paris: Albin Michel, 2000), 366. 
Advertíamos anteriormente de que la lógica de la obra del ministro-cardenal se definía por su novedosa jerarquía de principios en la dirección de los asuntos del reino, tanto en el interior como en el exterior. Ya fuera contra los hugonotes, contra la nobleza, contra el partido devoto o contra el Imperio, la línea de actuación del antiguo obispo se cifraba en el espíritu de la primacía de la política, y más concretamente, en esa máxima de la inteligencia política consistente, según Raymond Aron ${ }^{16}$, en convertir al enemigo de ayer en el aliado de hoy. La monarquía católica de Luis XIII no dudó en pactar con las fuerzas protestantes extranjeras al tiempo que combatía el cáncer hugonote de La Rochelle. Todo ello en nombre de la nueva razón de Estado. El Cardenal, según el retrato trazado por sus enemigos, llevaba en una mano el breviario y en la otra a Maquiavelo.

Conviene analizar el resultado de esta nueva lógica de pureza política en las relaciones internacionales e interiores. El nuevo escenario se tradujo intelectualmente en una intensificación de la laicización del pensamiento y el poder políticos. Para la legitimación política de una potencia católica tan emblemática como la monarquía francesa, el empeño de Richelieu exigía, máxime en el contexto de las guerras de religión, un argumento de autoridad que rebasara la dimensión estrictamente teológica con la que acostumbraban a ocultarse muchos de los conflictos que se presentaban en el tablero geopolítico. En este sentido, la apuesta de Armand du Plessis contribuyó a la purificación de un pensamiento político hasta entonces habituado a disfrazarse en nombre de causas morales y religiosas, contrarrestando con toda la energía teórica (y con munición esencialmente teológica) el creciente impacto que comenzaba a alcanzar la propuesta de desvelamiento de Maquiavelo. En el plano del concierto de las naciones, la política de Francia comenzaba a encontrar su propio argumento moral, pero un argumento de moral política que atendía al peligro representado por un Imperio unipolar que amenazaba el equilibrio geopolítico de la Cristiandad. Así, en una línea muy similar a la que defenderá después el teórico de la Acción Francesa, Charles Maurras, en su obra Kiel y Tanger (y que aplicará a rajatabla el general De Gaulle en la V República ${ }^{17}$ ), Francia se alzaba por primera vez como defensora de la multipolaridad en el concierto internacional. Su lugar y su misión consistían en ser el árbitro o mediador de la Cristiandad para preservar su equilibrio constitutivo.

16 Más precisamente: "Salvar a un enemigo cuando no se está seguro del aliado ha sido siempre muestra de una honorable sabiduría maquiaveliana". Raymond Aron, Memorias (Barcelona: RBA, 2013), 397.

17 Benjamin Fayet, "Kiel et Tanger de Charles Maurras: essai géostratégique visionnaire et source intellectuelle de la Vème République", Philitt, 19 de noviembre de 2014, consultado el 8 de marzo de 2020, https://goo.gl/MwcXQ3. 
Frente a la ambición española, el Estado más poderoso de Occidente tiene el deber de liberar a la Cristiandad de las amenazas que pesan sobre ella. Más aún, la expresión de la voluntad de la potencia francesa no excluye el deseo de restablecer un orden internacional. Al mismo tiempo que se afirma, el Estado nacional reconoce a los otros Estados. Por ello, en los numerosos escritos que precisan o exaltan el papel de Francia en Europa, una idea vuelve obstinadamente: la del equilibrio europeo que asegurará la libertad de los diferentes Estados. Sin embargo, en este segundo cuarto del siglo XVII, el equilibrio europeo ya no existe. Ha sido quebrado por la ambición desmesurada de España y le corresponde a Francia la misión de volver a colocar las cosas en su estado. Los escritores estatistas reivindican corrientemente para los franceses los títulos gloriosos de "liberadores" y de "árbitros de la Cristiandad". Esta manera de hablar era de las más oficiales. Richelieu mismo definió en estos términos los objetivos de la política francesa: “... ayudar a devolver la libertad a sus antiguos aliados, restablecer la paz en Alemania y volver a colocar las cosas en una justa balanza pues, en el estado presente la casa de Austria, en no más de seis años, cuando ya no tuviera nada más que conquistar en Alemania, intentaría ocupar Francia a nuestra costa". En nombre de la causa de la emancipación europea Richelieu justifica su intervención en los asuntos de Italia, Alemania y los Países Bajos. En cada acción militar o diplomática, se trata de liberar a un pueblo o un príncipe de la "opresión de los españoles", de la "tiranía de la Casa de Austria", del terror causado por la "avidez insaciable" de esta Casa enemiga del reposo de la Cristiandad, de detener sus "usurpaciones", de salvar a Italia de su "injusta opresión", de buscar su salvación ${ }^{18}$.

Aunque resulte paradójico, esta inquina propagandística contra la Casa de Austria no se oponía al atento sentido de la observación de su principal enemigo político. Una observación que alcanzó el rango de educación autodidacta por el método de la rivalidad estratégica. Luis Díez del Corral recordaba que "Richelieu admira la organización de la Monarquía española"19 aunque dicha admiración no podía traducirse por la pura y simple emulación de sus estructuras político-administrativas:

La imagen de España está presente en cada acto, en cada página del Cardenal. Muchas fueron las enseñanzas que recibiera, pero no tanto para imitar como para replicar, haciéndose configurador de un nuevo tipo de organización política que contrasta con la Monarquía de los Austrias, y sirve para iluminar su

18 Thuau, Raison d'État, 298-299.

19 Luis Díez del Corral, prólogo de La praxis política del absolutismo en el testamento politico de Richelieu, por Graciela Soriano (Madrid: Centro de Estudios Constitucionales, 1979), XII. 
naturaleza y su destino históricos. Especialmente aparece la temática española en el Testamento Político del Cardenal, obra que Carl J. Burkhardt considera le chef d'oeuvre de Richelieu; "un compendio de arte político, un método profundamente francés que conservará siempre valor de modelo"20.

En efecto, esta minuciosa observación de los movimientos del enemigo imperial no se tradujo en una "réplica mimética" de la configuración estructural del modelo imperial español sino en una réplica de un modelo estatal antagonista. Ese "método profundamente francés que conservará siempre valor de modelo" fue, en efecto, resultado de la guerra encabezada con mano de hierro por Richelieu, al que debe considerarse fundador, no solo de la Europa Moderna (como apuntaba Belloc), sino de la organización política estatocéntrica que la acompaña hasta hoy. Como apunta Dalmacio Negro: "La guerra fue una lucha entre el pueblo español y el Estado más perfeccionado de la época, que ha sido siempre desde Richelieu el paradigma o prototipo de la estatalidad. La Revolución y Napoleón lo convirtieron en el formidable Estado-Nación al que debió su superioridad" 21 . La consciencia de la superioridad del modelo francés para la guerra que se estaba librando alcanzaba también a los validos que se enfrentaban a él, pero la pervivencia de la forma mentis imperial impedía un mimetismo en sentido inverso hacia la centralización y concentración del poder que implementaba a marchas forzadas la corona francesa. Fue necesaria la importación de la dinastía borbónica para iniciar, y no sin resistencias, la lenta implementación del modelo estatal vecino.

Es notorio que Felipe IV rechazó la sugerencia en ese sentido del CondeDuque. Olivares se había dado cuenta de lo que estaba haciendo Richelieu en Francia, la primera gran potencia estatal con plena conciencia de lo que significa la soberanía moderna en orden a la centralización del poder político. Según Jouvenel, Olivares pensaba como el Cardenal, que el bien de la nación y del Estado justifica conculcar cualquier ley y privilegio, es decir, traspasar los límites que distinguen el poder de la potestas ${ }^{22}$.

La teoría del teórico francés Bertrand de Jouvenel sobre la ley de la competencia política en la narración de la "historia natural" del "crecimiento del poder" ofrece un molde histórico-teórico muy adaptado para comprender la relación directa entre la guerra librada por las dos monarquías católicas y la formación, a iniciativa de Richelieu, del nuevo modelo francés de Estado centralizado.

20 Díez del Corral, prólogo, X.

21 Dalmacio Negro, Sobre el Estado en España (Madrid: Marcial Pons, 2007), 71.

22 Negro, Sobre el Estado, 44. 
Estos celos naturales entre los poderes han engendrado, por un lado, un principio muy conocido cuyo olvido momentáneo los Estados suelen pagar muy caro: que todo aumento territorial de uno de ellos, al aumentar la base de la que saca sus recursos, obliga a los otros a buscar un aumento análogo para restablecer el equilibrio. Pero hay otra manera de reforzarse más temible para los vecinos que la adquisición territorial: el progreso de un poder en la explotación de los recursos que le ofrece su propio territorio ${ }^{23}$.

El propio Jouvenel señala el agudo apunte de Burke al entender este mismo fenómeno como experiencia a retener tras la Revolución Francesa cuando, en 1795, escribía:

El Estado [en Francia] es supremo. Todo está subordinado a la producción de la fuerza. El Estado es militar en sus principios, en sus máximas, en su espíritu, en todos sus movimientos... Si Francia tuviera más que la mitad de sus fuerzas actuales, seguiría siendo demasiado fuerte para la mayoría de los Estados de Europa, tal como están constituidos hoy y procediendo como lo ha$\operatorname{cen}^{24}$.

Jouvenel extrae una lección general de esta dialéctica entre la guerra y el crecimiento del poder: "todo progreso del poder respecto a la sociedad, ya se haya obtenido en vistas a la guerra o para cualquier otro objetivo, le otorga una ventaja en la guerra" 25 . Una ecuación que puede alterar el orden de los factores sin merma de su grado de validez histórica. Y es en este segundo sentido en el que se puede entender la tendencia hacia la concentración del poder a la que empujó esta puja mimética entre potencias antagonistas.

Así pues, si por una parte todo avance del poder sirve a la guerra, por otra parte la guerra sirve al avance del poder: actúa como un perro pastor que apremia a los poderes retardatarios a alcanzar a los más avanzados en el proceso totalitario. Esta íntima vinculación de la guerra y el poder aparece en toda la historia de Europa. Todo Estado que ha ejercido sucesivamente la hegemonía política se procuró los medios para ello a través de una presión sobre el pueblo más intensa que la ejercida por los otros poderes sobre sus pueblos respectivos. Y para hacer frente a estos precursores fue preciso que los poderes del continente se pusieran a su mismo nivel ${ }^{26}$.

23 Bertrand de Jouvenel, Sobre el Poder. Historia natural de su crecimiento (Madrid: Unión Editorial, 2011), 205-206.

24 Citado en Jouvenel, Sobre el Poder, 206. La cita de Edmund Burke corresponde a su obra Letters on a regicide Peace, publicada en 1796.

25 Jouvenel, Sobre el Poder, 206

26 Jouvenel, Sobre el Poder, 208. 
El autor de El Poder entiende que este proceso está muy vinculado a la resistencia francesa al Imperio español, al igual que sucedió en Inglaterra.

El desarrollo de la monarquía absoluta, tanto en Inglaterra como en Francia, está ligado a los esfuerzos de ambas dinastías para resistir a la amenaza española. Al ejército deberá Jacobo I sus grandes poderes. Si Richelieu y Mazzarino pudieron elevar tanto los derechos del Estado, fue porque podían invocar continuamente el peligro exterior ${ }^{27}$.

El testimonio de Fontenay-Mareuil (1594-1665), quien fuera diplomático y militar en la época de Richelieu, es especialmente relevante, a juicio de Jouvenel, para darnos "una idea de cómo la urgencia militar ha contribuido a liquidar las formas antiguas de gobierno y despejado el camino a la monarquía absoluta"28. En palabras del embajador francés:

Era realmente necesario para salvar el reino... que el rey tuviera una autoridad suficientemente absoluta para hacer todo lo que le pluguiera, ya que teniendo que habérselas con el rey de España, que dispone de tantos países para obtener todo lo que precisa, es claro que si hubiera tenido que reunir los Estados Generales, como se hace en otros lugares, o depender de la buena voluntad del parlamento para obtener todo aquello de que tuviera necesidad, jamás habría podido hacerlo ${ }^{29}$.

Las cifras de la población militar francesa bajo el mando de Richelieu son un indicador bastante revelador de la transformación llevada a cabo en Francia como resultado de la confrontación política y armada con el Imperio de los Habsburgo:

Richelieu, que se encontró con que todas las fuerzas de Francia habían sido reducidas por María de Médicis a 10000 hombres, las elevó a 60000; luego, tras haber mantenido durante mucho tiempo la guerra en Alemania, "echando mano a la bolsa más bien que a la espada", pone en pie un ejército de 135000 soldados de infantería y 25000 de caballería, unas fuerzas que Francia no ha conocido en ocho siglos ${ }^{30}$.

Nada mejor que el testimonio del propio Richelieu para entender este desorbitado crecimiento de los recursos puestos a disposición de la nueva maquinaria estatal. El cardenal lo justificó por el "incesante propósito de frenar el avance

27 Jouvenel, Sobre el Poder, 211.

28 Jouvenel, Sobre el Poder, 211.

29 Citado en Jouvenel, Sobre el Poder, 211.

30 Jouvenel, Sobre el Poder, 211. 
de España"31. La guerra, comadrona de la monarquía absoluta, no solo enterraba así a las viejas aristocracias (confirmando el aserto de Vilfredo Pareto sobre la circulación de las élites) sino que también se preparaba para el funeral de la forma imperial española, sin cuya amenaza no hubiera surgido el gigantesco aparato que, surgido por la fuerza de las circunstancias para la defensa de la nación francesa, ya iniciaba la senda hacia ese organismo autónomo deseoso de explotarla, como sugería el escolio de Gómez Dávila.

\section{MAQUIAVELO AFRANCESADO.}

En Francia, el éxito de este nuevo modelo nacional en competencia con el Imperio no podía dejar de entenderse fuera de las exigencias históricas de una adaptación del discurso a las particulares relaciones que, en el marco de la Contrarreforma católica, se imponían entre la religión y la política. En este corsé doctrinal y teórico, el saber político pugnaba por alcanzar todo el margen de autonomía posible para atender las exigencias de una confrontación entre potencias católicas enfrentadas. En ese contexto cultural, era evidente que Francia tenía todas las de perder frente a una potencia imperial tan universalista en sus aspiraciones como la misma Iglesia, y por ese mismo motivo, más legitimada teóricamente para imponer sus derechos a la hegemonía política ante el tribunal doctrinal que tutelaba las ideas y mentalidades de una época necesitada de justificación teológica. En este sentido, la apuesta de Richelieu por la propaganda de las ideas de los llamados "católicos de Estado"32 también debe considerarse como uno de los éxitos de su labor al frente de la dirección de los asuntos políticos de la corona francesa. Una batalla intelectual se estaba librando, en paralelo a la batalla política y militar, y la recepción crítica en el mundo católico de la obra de Maquiavelo formaba parte central de la controversia. Mientras que en Francia, por necesidades de su posición geopolítica defensiva frente a la supremacía del orden imperial, comenzaba a asumirse la imperiosa necesidad de una escisión entre la ética y la moral cristianas y las exigencias derivadas del ejercicio del poder político, en España no cabía la asimilación de un discurso maquiaveliano opuesto frontalmente a los talismanes legitimadores nacionales desde la Reconquista ${ }^{33}$ :

La obra de Maquiavelo, con su crítica política e histórica de la moral cristiana y del papado, no podía competir en una España en la que el Estado hacía del

31 La cita del Cardenal aparece en Jouvenel, Sobre el Poder, 211.

32 Thuau, Raison d'État, 180-182.

33 Sin embargo, el tacitismo ha sido juzgado como forma de "criptomaquiavelismo" muy difundido en los países católicos. Cf. Yves-Charles Zarka, Raison et déraison d'État (París : PUF, 1994). 
catolicismo cada vez más su fundamento basilar y que situaba en el refugio de Covadonga el principio mítico de su construcción estatal y expansión imperial $^{34}$.

Sin duda, merece atención esta frustrada asimilación por las elites españolas del nuevo discurso político de una propaganda que, al servicio de la monarquía francesa, reivindicaba cada vez con mayor claridad la legítima autonomía de la razón de Estado en el marco del pensamiento católico, al tiempo que denunciaba como espurios los argumentos teológicos con los que los españoles pretendían disfrazar, de acuerdo con esta interpretación, una hegemonía política y militar que servía exclusivamente a sus propios intereses.

Ya en 1623, la France mourante mostraba qué peligro presentaba para Francia la política del rey de España: “... si dejamos fortalecer sus conquistas, es muy seguro que se volverá dueño de toda Italia, y dominador de las Alemanias, y por este medio cercará a esta corona por todas partes por potencias tan grandes que será imposible que pueda resistir" [...]. El Discours sur plusieurs points importants (1626) denuncia a “... aquellos que han aspirado siempre al Imperio del Universo". La Lettre déchiffrée (1627) ataca a la política española que quiere "... levantar los asuntos del cielo al nivel de los de Madrid" y para quien "todo lo que se hace por el Vaticano es criminal si no es ratificado en el Escorial". [...] En 1626, el prefacio de la Pierre de touche politique precisa así la inspiración del libro: “... destapa el propósito que los españoles tienen de oprimir a todos sus vecinos con el pretexto de la Religión y de la Caridad, y de establecer por ese medio su Monarquía Universal, y muestra que esta nación siempre ha tenido el interés de Dios y de la Iglesia en la boca, y no lo ha tenido nunca en el corazón”. Después de la acusación de imperialismo, el reproche más frecuentemente dirigido a los españoles es el de emplear lo espiritual para fines temporales ${ }^{35}$.

Este nuevo arsenal argumentativo anti-imperialista no era fabricado de manera completamente espontánea. Venía impulsado por la munición teórica del mismísimo cardenal Richelieu, que no dudaba en señalar las servidumbres políticas de la "teología española" de la época.

Richelieu, en sus Memorias, denuncia los pretextos españoles. Los panfletos de política extranjera no cesan de atacar la "nueva teología" fabricada por España para cubrir sus ambiciones. [...] Está por tanto bien asentado en el credo político de los "buenos franceses": cuando los españoles defienden el

34 Juan Manuel Forte y Pablo López, introducción de Maquiavelo y España. Maquiavelismo y antimaquiavelismo en la cultura española de los siglos XVI y XVII (Madrid: Biblioteca Nueva, 2008), 35.

35 Thuau, Raison d'État, 198-199. 
cristianismo, podemos estar seguros de que es el cristianismo el que defiende a los españoles ${ }^{36}$.

En el combate entre el Imperio y la nueva forma estatal del modelo francés se ventilaba también una lucha en el campo del pensamiento político, con la particularidad de que esta controversia teórica se producía dentro del marco religioso de legitimidad católica en el que Francia parecía contar, por sus derechos de primogenitura como hija mayor de la Iglesia, con unas credenciales que podían competir con los del Sacro Imperio. Pese a la indudable superioridad de la forma estatal para responder a los retos y desafíos de la confrontación que se dibujaba en el tablero geopolítico, España no podía asumir esos nuevos usos que chocaban frontalmente tanto con su propia tradición jurídica y política como con su historia política de reconstrucción nacional (la Reconquista), tan apegada a un discurso religioso de legitimación que no cabía en él la más mínima escisión para una razón de Estado independiente de la tutela de la fe. En cambio, este carácter nacional y esta personalidad histórico-político-religiosa parecían encajar mucho mejor con el relato imperial, máxime en una época marcada por una Reforma protestante que reforzaba los derechos de justificación de la ortodoxia religiosa para imponer el orden universal de la espada de Roma. Estas raíces explican, en gran medida, la costosa asimilación del modelo estatal en tierras hispanas.

En cuanto al pensamiento político español, se vio forzado, en palabras de Abellán, a tener que vivir "de hecho" bajo una forma política, "el Estado", en la que, sin embargo, "no se creía teóricamente". Y quizá es cierto que los autores españoles no creyeron mucho en el "Estado moderno" pero no tanto porque la religión se lo impidiera, sino porque creyeron más bien en algo que no era exactamente el Estado moderno: un Imperio católico ${ }^{37}$.

A diferencia de España, en Francia se contaba con todas las razones del mundo para creer en la forma política estatal, y si faltaban razones, no se dudaba en inventarlas tanto como fuera necesario. La autonomía de las exigencias de la política frente a los imperativos de la religión fue sin duda la filosofía central de la nueva propaganda de la monarquía francesa y el núcleo del que se desprendían todas esas razones. Y era el mismo Richelieu quien la ponía por delante al aseverar, en frase ya célebre y con toda la autoridad religiosa de la que era capaz

36 Thuau, Raison d'État, 375.

37 Juan Manuel Forte y Pablo López, Maquiavelo y España, 39-40. 
un príncipe de la Iglesia, que los intereses de Estado son diferentes de los intereses de la salvación de las almas ${ }^{38}$.

Colocada entre sus aliados protestantes y la católica España, la Francia de Richelieu se encontraba ante una opción difícil. Estado o religión: tal era el dilema que se planteaba en la conciencia de numerosos franceses y los escritos de la época atestiguan su malestar. [...] En otro tono, Richelieu no decía otra cosa y, en las instrucciones a Schomberg a menudo citadas, podemos leer: "distintos son los intereses del Estado que ligan a los príncipes de los intereses de la salvación de las almas" ${ }^{" 39}$.

Interesa a este respecto la vinculación entre esta nueva laicización del pensamiento político y la forma política estatal. Además del interés que suponía para la propaganda teórica al servicio del Cardenal esta apuesta por un realismo político liberado de ataduras religiosas, existe una indudable propensión favorable del esquema estatal hacia las figuras intelectuales del pensamiento político más laico. Estas figuras encontraban cierta dificultad para abrirse paso en la estructura de legitimidad de la forma imperial, demasiado impregnada por el peso de lo sagrado (el "Sacro" Imperio) y por la voluntad de imponer una cosmocracia de ambiciones universalistas que, al modo de Campanella, forzosamente contaminaba o disolvía los binomios políticos del conflicto en su más puro sentido (amigo/enemigo).

\section{LA CREACIÓN POLÍTICA FUERA DE LA POLIS}

Sheldon Wolin ha analizado la faceta creativa inherente al pensamiento político y su aportación disruptiva recurrente entre las líneas de continuidad de la tradición occidental heredada, así como la relación de estos saltos creativos con las transformaciones históricas de las formas políticas ${ }^{40}$. Para Wolin, originariamente, el pensamiento político era relativo a los problemas característicos de la polis, es decir, a su tamaño, problemas e intensidad, rasgos que ofrecían un marco general marcado por una efervescencia muy definitoria de una forma de vivir y convivir en el espacio público. Esta sencilla intuición se traduce inmediatamente en otra pregunta. Si el pensamiento político es un pensamiento relativo a los problemas de la polis, ¿puede sobrevivir ese mismo modelo de

38 "Autres sont les intérêts d'État qui lient les princes et autres les intérêts du salut de nos âmes". Armand Jean du Plessis de Richelieu, Mémoires du Cardinal de Richelieu, sur le règne de Louis XIII: depuis 1610 jusqu'à 1638. Tome 1. Années 1610 à 1619 (París: Foucault, 1823), 618.

39 Thuau, Raison d'État, 204-205.

40 Sheldon Wolin, Política y perspectiva. Continuidad e innovación en el pensamiento político occidental (México DF: Fondo de Cultura Económica, 2012). 
pensamiento en los contextos relativos a otras formas políticas? En otras palabras, ¿cómo afecta al pensamiento político una configuración espacial extraña a los límites espaciales, preocupaciones e intensidad conflictiva de la polis?

El contraste entre la "nerviosa intensidad" del pensamiento político griego, apegado a las dimensiones y efervescencia de la polis, y otras sensibilidades humanas características de una concepción espacial diferente se planteó por primera vez en relación con el "talante del estoicismo posterior que ociosamente y sin el sentimiento de urgencia apremiante contempló la vida política mientras se manifestaba en un entorno tan espacioso como el universo mismo"41. Este primer contraste ya anunciaba la influencia decisiva que esta nueva sensibilidad espacial universalista, definitoria de la forma imperial, iba a imprimir en la configuración del pensamiento político, empobreciendo y difuminando sus categorías esenciales.

[...] El hecho fundamental desde la muerte de Alejandro hasta la absorción final del mundo mediterráneo en el Imperio romano fue que las condiciones políticas ya no correspondían a las categorías tradicionales del pensamiento político. El vocabulario griego podría reunir la pequeña polis y las desperdigadas ligas de ciudades bajo la palabra única koinón, pero no se podía ignorar el hecho de que la ciudad denotaba una asociación intensamente política, mientras que las ligas, monarquías e imperios que siguieron a la decadencia de la polis eran organizaciones esencialmente apolíticas. Por consiguiente, si la tarea histórica de la teoría política griega había sido descubrir y definir la naturaleza de la vida política, delegó en el pensamiento helenístico y más tarde el romano la labor de redescubrir qué significado podría tener la dimensión política de la existencia en una época imperial ${ }^{42}$.

El modo de superar las dificultades asociadas a la nueva representación social del espacio (las enormes distancias que ahora se imponían frente a la acostumbrada relación de proximidad ciudadana que definía la atmósfera política griega) consistió en una recuperación del simbolismo sagrado, que iba a fundirse desde entonces con el discurso de legitimidad de las formas imperiales.

Mientras que la lealtad anteriormente había provenido de un sentimiento de participación común, ahora se centraba en una reverencia común por el poder personificado. La persona del gobernante servía como punto de concentración de lealtades, el núcleo común que vinculaba las partes diversas del imperio. En este sentido, el empleo del simbolismo fue particularmente importante porque mostró cuán valiosos pueden ser los símbolos para conectar

41 Wolin, Politica y perspectiva, 98.

42 Wolin, Política y perspectiva, 102. 
amplias distancias. Sirven para evocar la presencia de la sociedad a pesar de que la realidad física esté muy alejada ${ }^{43}$.

El impacto de esta nueva configuración de las dimensiones de la relación de los hombres sometidos al nuevo poder imperial no solo arruinó las clásicas categorías de ciudadanía del pensamiento griego sino que también alteró la estructura moral y concreta (esa simbiosis tan característica entre ética y sentido práctico) de una percepción de lo político marcada por una cercanía con los problemas reales del espacio público y una experiencia directa de sus conflictos asociados. Frente a esa hiperestesia del realismo político griego se alzaba ahora una concepción crecientemente abstracta de la vida política, que requería en la misma medida el socorro de un aparato teórico y simbólico hermanado con la morfología de una comunidad sin contornos definidos, y que desbordaba los límites y fronteras de las vívidas representaciones para adentrarse en el espacio infinito abierto por conceptos y categorías universales.

Con el desarrollo de la organización imperial, la sede del poder y de la toma de decisiones se había alejado mucho de las vidas de la gran mayoría. Parecía existir muy poca conexión entre el entorno que rodeaba las decisiones políticas y el pequeño círculo de experiencias del individuo. En otras palabras, se hacía política en una forma incomprensible para las categorías del pensamiento y la experiencia ordinarios. La "política visual" de una época anterior, cuando los hombres podían ver y sentir las formas de acción pública y establecer comparaciones significativas con su propia experiencia, cedía el paso a la "política abstracta", la política desde cierta distancia, donde a los hombres se les informaba acerca de acciones públicas que tenían poca o ninguna semejanza con la economía de la familia o los asuntos del mercado. En estas circunstancias, los símbolos políticos eran recordatorios esenciales de la existencia de la autoridad ${ }^{44}$.

La nueva sensibilidad cósmica, iniciada por el cosmopolitismo estoico y que tan bien se adaptaba al ethos del poder imperial (personificándose incluso en figuras egregias como Marco Aurelio), estaba llamada a hermanarse, si no a fundirse, con ambiciones soteriológicas de signo religioso, máxime cuando, pasado el tiempo, la forma Imperio iba a proclamar al cristianismo como religión oficial.

Otro impulso, mucho más fuerte pero igualmente apolítico, fue revestir el poder de símbolos e imágenes religiosos. [...] Este fue un signo seguro de que los hombres habían llegado a considerar el régimen político como algo

43 Wolin, Politica y perspectiva, 102-103.

44 Wolin, Política y perspectiva, 103. 
por encima de sus necesidades materiales e intelectuales, algo similar a la salvación $^{45}$.

A partir de entonces, y a pesar de las reservas teológicas de un San Agustín frente a la teología política de Varrón, el momento histórico-político se encontraba en la mejor disposición para correlacionar las categorías religiosas y las políticas hasta el punto de fomentar una política legitimada por la teología y una teología refrendada por las formas políticas existentes.

Esta creencia en un salvador político, así como los persistentes intentos de equiparar al gobernante con una deidad y describir el gobierno de la sociedad humana como análogo al gobierno de Dios sobre el cosmos, eran temas que reflejaban el grado en que los elementos políticos y religiosos se habían mezclado profundamente en la mente de los hombres. [...] Al mismo tiempo, a partir del siglo IV a.C. hasta ya avanzada la era cristiana, los hombres repetidamente concibieron a la deidad en términos principalmente políticos. De ese modo, se produjo la situación paradójica en que la naturaleza del gobierno de Dios era interpretada mediante categorías políticas y la del gobernante humano, mediante categorías religiosas; la monarquía se convirtió en una justificación del monoteísmo y el monoteísmo justificó a la monarquía ${ }^{46}$.

No es necesario apelar excesivamente a la imaginación para entender que esta nueva mentalidad contribuyó inopinada pero decisivamente a desdibujar progresivamente la pureza de unos conceptos políticos que habían crecido al calor de la intensidad conflictiva de la vida ciudadana griega. Las categorías políticas que habían poblado el espíritu de los principales filósofos griegos no habían nacido de la especulación abstracta sino de la vida cívica que, significativamente, muchos de ellos habían experimentado en sus propias carnes. De este modo, el advenimiento de la era imperial arrastró, si no la ruina de las categorías políticas heredadas de la filosofía griega, sí al menos la experiencia inherente al modo de pensamiento político del logos griego, generando así un temperamento colectivo alejado de él, y unas formas de pensamiento crecientemente apolíticas.

Cuando examinamos en retrospectiva las especulaciones políticas que siguieron a la muerte de Aristóteles, resulta evidente que se representó con fidelidad el carácter apolítico de la vida y que no apareció ninguna filosofía verdaderamente política. Muchas veces lo que había pasado por pensamiento político

45 Wolin, Politica y perspectiva, 120.

46 Wolin, Política y perspectiva, 121. 
fue radicalmente apolítico: se había buscado el significado de la existencia política sólo para que los hombres pudieran escapar más fácilmente de ella ${ }^{47}$.

Inevitablemente, desde ese mismo momento, ya se abría, a través de infección del simbolismo sagrado en las formas imperiales, una vía para la penetración de unos maniqueísmos morales que iban a solaparse progresivamente con los binomios definitorios de la esencia de lo político, tal y como han sido estudiados por ejemplo por Julien Freund ${ }^{48}$, especialmente el binomio amigoenemigo para las relaciones exteriores y el binomio mando-obediencia para las interiores. El mundo político, para este nuevo moralismo, se dividía a partir de ahora en "buenos" y "malos" (vale decir, fieles e infieles, ortodoxos y herejes), quebrando así la delimitación espacial y teórica que entre lo político y lo ético había edificado el realismo de autores como Tucídides. A partir de ahora, ya no existía una moral "política" (esto es, una moral adaptada a las exigencias de la realidad política) sino que lo político (todo lo político, con su arsenal teórico y práctico) se sometía a "la" moral, una moral única y universalista llamada a ser colonizada, andando el tiempo, por una fe (la cristiana) que, a diferencia de los otros dos monoteísmos (el judío, que le precedía, y el musulmán, que le sucedió), no había abrigado en su seno, paradójicamente, ambición alguna de carácter político.

En lugar de redefinir las nuevas sociedades en términos políticos, la filosofía política se convirtió en una especie de filosofía moral que no se dirigía a esta o aquella ciudad, sino a toda la humanidad. [...] El suicidio de Séneca fue el símbolo dramático de la quiebra de una tradición de filosofía política que había intercambiado su elemento político por un moralismo insulso ${ }^{49}$.

De este nuevo escenario, que terminó por imponerse a la postre, podemos rescatar llamativos precedentes que, como a modo de anticipos simbólicos, se presentaron en el inédito experimento imperial alejandrino. El griego Erastóstenes encarna ante la historia la figura de un consejero antischmittiano avant la lettre, que conquista para la moral el territorio hasta entonces virgen de lo político.

Cuando Eratóstenes aconsejó a Alejandro que ignorara la distinción de Aristóteles entre griegos y bárbaros y gobernara en cambio clasificando a los hombres en buenos y malos, constituyó no sólo un paso hacia una concepción de igualdad racial, sino también una etapa en la declinación de la filosofía

47 Wolin, Política y perspectiva, 122.

48 Julien Freund, La esencia de lo político (Madrid: Centro de Estudios Políticos y Constitucionales, 2018).

49 Wolin, Politica y perspectiva, 122-123. 
política. [...] El Consejo de Eratóstenes indicaba que el pensamiento político, como la misma polis, había sido sustituido por algo más amplio, más vago y menos político. Lo "moral" había superado a lo "político" porque la moral y lo "bueno" ahora se definían en relación con lo que trascendía a determinada sociedad en el tiempo y el espacio ${ }^{50}$.

En conclusión, el ocaso histórico de la polis, entendida como relación espacial adaptada de lo humano para con lo político, arrastró al pensamiento político originado por aquella hacia un hábitat intelectual, religioso y moral menos adaptado para su supervivencia intelectual. En ese medio ambiente, que fue el del Imperio primero y el del feudalismo después, la filosofía política languideció. Aunque preservó su vigencia teórica en un mausoleo en el que se congeló a través de los siglos el eco de un vocabulario nacido de un microcosmos claustrofóbico de rivalidades intestinas, aguardó su resurrección a la espera de un entorno idóneo para la palingenesia.

Al parecer, la decadencia de la polis como centro nuclear de la existencia humana había privado al pensamiento político de su unidad básica de análisis, a la cual no pudo reemplazar. Sin la polis, la filosofía política se había reducido al estado de material intelectual en busca de un contexto pertinente ${ }^{51}$.

El contexto pertinente para la regeneración del pensamiento político apareció en un universo que en parte recordaba al de las antiguas polis griegas. El aire en ebullición que se respiraba en las repúblicas italianas del Renacimiento oxigenó a las mentes capaces de restituir una comprensión más cabal de las nuevas (y las viejas) realidades políticas, que se presentaban otra vez bajo un nuevo día. Maquiavelo fue el epítome teórico del moderno firmamento político pero la atmósfera explica el fenómeno. "Casi un siglo antes de que se escribiera El príncipe, se había desarrollado una tradición viable de 'realismo' en el pensamiento político italiano" ${ }^{52}$, recuerda Wolin.

Sin embargo, esta nueva sensibilidad hacia las cuestiones políticas tardaría en abrirse paso y lograr un reconocimiento definitivo. La inercia del viejo mundo seguía oponiéndole el peso de una tradición de simbiosis político-religiosa. No es de extrañar que la mariposa política no saliera de la crisálida definitivamente hasta que esas nuevas categorías no fueran asumidas precisamente en el hábitat religioso que lo condicionaba. Las monarquías nacionales nacientes ofrecían un marco incomparable para el ensayo de esta nueva oferta de comprensión del hecho político. En monarquías capitaneadas por hombres de Estado

50 Wolin, Politica y perspectiva, 122-123.

51 Wolin, Política y perspectiva, 122.

52 Wolin, Politica y perspectiva, 238. 
que eran al mismo tiempo príncipes de la Iglesia, como en la Francia de Richelieu, el obstáculo de la legitimación teológica podía superarse con mayor holgura. En el contexto geopolítico de guerras religiosas cuyas exigencias morales difícilmente podían compaginarse con la incipiente razón de Estado, la fusión de lo político con lo religioso, lejos de ser un obstáculo para la autonomía del primero, se presentaba como su única (y mejor) plataforma de lanzamiento hacia ella. La siguiente reflexión de Wolin, de alcance mucho más amplio en su intención, permite sin embargo una interpretación en clave francesa que ofrece un poderoso marco de análisis para entender la progresiva laicización del pensamiento político en la Francia gobernada con mano de hierro por el "hombre de rojo".

La creciente fusión de categorías políticas y religiosas del pensamiento fue una consecuencia intelectual de la propagación del control político sobre las iglesias nacionales. Cuando estas tendencias se unieron al cada vez mayor poder de las monarquías nacionales y a una incipiente conciencia nacional el efecto combinado fue plantear una posibilidad que no había sido considerada seriamente en Occidente por casi mil años: un orden político autónomo que no reconocía algo superior y que, si bien aceptaba la validez universal de las normas cristianas, insistía terminantemente en que la interpretación de esas normas era un asunto nacional. [...] En la medida en que la teoría política contenía un elemento obstinadamente moral y en la medida en que los hombres identificaran los imperativos categóricos últimos con las enseñanzas cristianas, el pensamiento político se resistiría a ser despojado de las imágenes y valores religiosos ${ }^{53}$.

Es indudable que el nuevo escenario político y religioso poco tenía que ver con el de las polis griegas en las que habían nacido y vivido hombres como Platón, Aristóteles o Tucídides. Habían pasado casi dos milenios y los hombres del siglo XVI y XVII vivían sumergidos en los dogmas de una fe que desconocieron los griegos de la Antigüedad. Sin embargo, lejos de lo que pudiera parecer a primera vista, el espíritu de laicidad que caracterizaba genuinamente la letra (y el espíritu) de los creyentes en Jesucristo estaba aguardando un contexto favorable para la conquista definitiva de una autonomía política que no contradecía tan gravemente sus postulados como en el caso de los que seguían la ley de Moisés o de Mahoma. Más aún, como recuerda Jerónimo Molina, el pesimismo antropológico de la concepción política de un Maquiavelo era deudor involuntario de la teología cristiana ${ }^{54} \mathrm{y}$, aunque los ecos del creador de $E l$

53 Wolin, Politica y perspectiva, 236.

54 Jerónimo Molina, 8 de marzo de 2020, "Cristo, maestro de Maquiavelo, Blog Nada en Las Manos, 8 de mayo de 2012, https://goo.gl/HknzTh. 
Príncipe parecen resonar en la historia de la guerra del Peloponeso, la profundidad del equipamiento intelectual sobre la condición del hombre que distinguía al florentino como resultado de más de 1500 años de tradición cristiana no estaba al alcance de un militar como Tucídides.

Esta tendencia pesimista, que surgió de la comprensión de que el nuevo conocimiento debía ser versado en el mal y que su mayor problema era evitar el infierno, confirma que fue una ciencia poscristiana, más que una inspirada directamente por modelos clásicos. La afirmación de que "todos los hombres son malvados y que darán rienda suelta a la malignidad que hay en ellos cuando se presente la oportunidad" ${ }^{\prime 55}$ fue una idea que nunca albergó la ciencia política griega y de la cual nunca dudó la doctrina cristiana ${ }^{56}$.

\section{LAICIZACIÓN Y RAZÓN “CATÓLICA” DE ESTADO}

En este contexto de oposición francesa a un poder imperial que cifraba su legitimidad política en una autoridad que apelaba a argumentos de carácter religioso, la autonomía de lo político no apareció como resultado de una construcción intelectual independiente sino de las exigencias de una propaganda al servicio de una acción militar y política determinada por una atmósfera de hegemonía religiosa en el terreno de la argumentación sobre las realidades temporales.

Descubierta o redescubierta por los estatistas de la época de Richelieu, la idea de autonomía de la política no sale de la pura especulación, sino de toda una serie de conflictos concretos: querella del galicanismo, problema de relaciones con los protestantes, y sobre todo conflicto franco-español. El principio de la independencia de la política fue el arma anti-española por excelencia ${ }^{57}$.

Todo ello explica que el curso del debate desembocara en conclusiones probablemente imprevistas. Lo prueba el hecho de que la propaganda cardenalista aceptara el reto de la fundamentación religiosa de las razones teóricas a presentar frente a las reivindicaciones españolas. España había elegido mal enemigo para sustentar la superioridad sagrada de su causa. La hija primogénita de la Iglesia no dudaría en empalmar con los cimientos de una misión divina tan frecuentemente destacada por la sede petrina.

55 Nicolás Maquiavelo, Discursos, libro primero, 3. Referencia del libro citado.

56 Wolin, Política y perspectiva, 284.

57 Thuau, Raison d'État, 370. 
La religión de la monarquía no podía sino confirmar a los franceses en la idea de que su país tenía una misión y que continuaba la tradición de las Gesta Dei per Francos tan bien expresada por las palabras de Juana de Arco: “Aquellos que hacen la guerra al Santo Reino de Francia hacen la guerra al Rey Jesús" ${ }^{58}$.

Con todo y con eso, la dialéctica religiosa empleada en el conflicto no dejaba de ser, para los intereses políticos de la monarquía francesa, un arma defensiva diseñada específicamente para contrarrestar la ofensiva de los Habsburgo, por mucho que no fueran pocos los que la utilizaran con pleno convencimiento. Poco a poco, los argumentos estrictamente políticos pasaban a ocupar el primer plano del escenario, mientras que la retórica religiosa se situaba progresivamente en el espacio del decorado. Al fin y al cabo, la confrontación de las dos más grandes potencias católicas de la época no era el terreno más apropiado para una resolución del conflicto en sede religiosa. Al tratarse de una pugna marcadamente política era inevitable que fueran los argumentos políticos los que se abrieran paso paulatinamente para ocupar el espacio de mayor protagonismo.

El Católico de Estado no fue solo el nombre de uno de aquellos panfletos gubernamentales al servicio de la política de Richelieu. El nombre elegido por aquella publicación indica la inspiración general de su contenido. Sin duda alguna, este periódico, aparecido al comienzo del ministerio de Richelieu en 1624, se distinguió por su vigor doctrinal en su defensa de la nueva política del cardenal. El título exacto era Le Catholique d'État ou discours politique des alliances $d u$ roi très chrétien contre les calomnies de son État. Como han destacado los estudiosos de la prensa de la época, este panfleto constituye el núcleo duro de la propaganda al servicio del ministro de Luis XIII. El panfletario cardenalista se subleva contra el desprecio intelectual y moral que en la época se dirigía a la asociación de la figura del "católico" y la idea de "la política de Estado". De este modo, colocará con orgullo en su mismo título el espíritu de esta asociación elevándola al rango de comunión nacional y religiosa y haciendo la apología de aquellos que, como los soberanos de Francia, saben conjugar los intereses del Estado y de la Iglesia católica. No obstante, a la postre (y más allá de las intenciones inmediatas de sus promotores) el empuje de su argumentario doctrinal contribuyó a disociar progresivamente la fundamentación del orden político de todo horizonte religioso, reelaborando los cimientos de un realismo político aparejado al análisis interesado de la posición francesa en el conflicto contra el Imperio español. 
La paradoja del Catholique d'État reside en el hecho de que después de haber fundado el absolutismo sobre una concepción autoritaria de la religión llega a separar la política de la religión. No aproxima el poder de Dios sino para asegurar mejor su independencia. [...] rechazando los argumentos religiosos de la propaganda española y subrayando la separación de la política y de la moral, el Catholique d'État recoloca el conflicto de Francia y España bajo su luz verdadera: el de la confrontación de dos intereses nacionales"59.

Como consecuencia de esta creciente traslación -del espacio de definición religiosa hacia el terreno de definición política- la terminología del escrito cardenalista colorea progresivamente el binomio amigo-enemigo de la oposición política con caracteres nacionales y no religiosos, afirmando así una delimitación intelectual del conflicto en términos cada vez más cercanos a la significación real de la confrontación política.

Mientras que los panfletos extranjeros separan a los hombres en cristianos e impíos, el Catholique d'État se coloca en otra óptica. [...] Así, en el escrito cardenalista, la distinción amigo-enemigo, capital en el pensamiento político, se funda a partir de ahora, no ya en la religión, sino en la nacionalidad y el patriotismo $^{60}$.

Así pues, a partir del estudio de publicaciones propagandísticas como el Catholique d'État, es posible analizar el sentido general de un proceso de paulatina decantación doctrinal. Si bien la oposición contra el Imperio católico obligaba a una respuesta en el terreno teológico (o más exactamente, en el terreno teológico-político), la prolongación del conflicto imponía, además de la refutación de los "pretextos" religiosos del enemigo con la misma munición católica que este empleaba, una necesaria transferencia del epicentro de la confrontación intelectual hacia un territorio político no abonado por la semilla teológico-moral. Sin esta circunstancia histórica (fundamentalmente política y militar, además de religiosa) que rodea la publicación cardenalista, no se puede entender la "paradoja" del Catholique d'État.

No exento de cualidades literarias, el Catholique d'État contiene en abreviado la teoría del Estado autoritario del reino de Luis XIII y define el ideal de un "católico político", del "buen patriota". Su paradoja consiste en partir de una concepción religiosa del poder para llegar a separar la política de la religión o, más exactamente, de una religión entendida a la manera española. [...]

59 Thuau, Raison d'État, 191.

60 Thuau, Raison d'État, 192. 
Desarrollando una nueva concepción de la política, dejan presentir esa laicización del poder que será el rasgo dominante de la época de Richelieu ${ }^{61}$.

El nuevo clima originado por el conflicto franco-imperial iba a propiciar un estado de ánimo tendente a considerar con sospecha los pretextos religiosos aducidos por un enemigo hispano-austriaco maliciosamente inclinado, a ojos de la propaganda cardenalista, a situar el epicentro teórico de la confrontación en el espacio doctrinal más adaptado a su propio beneficio. Esta sospecha contribuyó, inconscientemente, a desautorizar la legitimación religiosa de las causas políticas, al presentarla como un velo empleado interesadamente por una mano decidida a ocultar el verdadero rostro de su dueño.

La semejante disposición de las piezas en el tablero entre los dos contendientes (potencias católicas que rivalizaban en autoridad moral en una atmósfera de hiperlegitimidad religiosa) originó la inopinada transformación de las reglas del juego hasta entonces vigentes y con ella la consecuente laicización del pensamiento político. Puede decirse que la hegemonía imperial española hizo emerger una razón (católica y francesa) de Estado.

La consecuencia de este proceso a España y a sus partidarios es, sin duda, la de volver sospechosas las justificaciones religiosas en política. Se observa aquí un detalle curioso de la historia del pensamiento político en el siglo XVII: la idea de que la religión es un engaño de los gobernantes y un secreto de la dominación ha sido difundida por los publicistas del rey muy cristiano escribiendo contra los panfletarios del rey muy católico. La concepción que hace de la religión una impostura de los poderosos ha sido, si no producida, al menos reforzada por la confrontación de grandes Estados nacionales. Convertida así la religión en sospechosa, ¿qué podía quedar como ley de las relaciones internacionales sino el interés de cada Estado y el derecho natural? Y, en efecto, si se busca la base que los escritores estatistas dan a la política de Richelieu, se constata que invocan cada vez más el interés nacional y la razón de Estado. Sin duda no hacen del reino de Francia un Estado laico pero se ven conducidos a separar más netamente que sus predecesores y que sus adversarios los intereses del Estado de los de la religión. El hecho de que España y sus partidarios insistan en la unión de la fe y de la política contribuye mucho sin duda a esta laicización. [...] si todavía mezclan argumentos religiosos y argumentos racionales, el predominio de estos últimos es sensible ${ }^{62}$.

61 Thuau, Raison d'État, 193.

62 Thuau, Raison d'État, 203-204. 
"Así -escribe Ethienne Thuau-, la razón de Estado se prepara para convertirse en el argumento mayor de la política de Richelieu"63. Esta "política del desvelo", una forma peculiar de maquiavelismo a la francesa en clave nacionalcatólica, debe ser entendida como la necesaria reacción a un contexto determinado. La incómoda verdad de un realismo político depurado de mistificaciones morales y disfraces teológicos no pudo abrirse paso sin atender a dicho contexto.

Parece que en la época de Richelieu los publicistas proespañoles hayan optado por la política del velo y los panfletarios franceses por la del desvelo. [...] Así, a los ojos de muchos franceses del siglo XVII, la "ingenuidad" gala se opone a la hipocresía española. Esta ingenuidad consiste en un primer momento en revelar a un público limitado los resortes del poder y a conducir al profano entre las bambalinas del gobierno. Más profundamente, tiende a desacralizar el poder y a desprenderlo de las justificaciones morales y religiosas con las que se recubre a menudo ilegítimamente. La verdad no siempre es agradable de decir y es a su lucidez a la que se debe, como para Maquiavelo, su mala reputación ${ }^{64}$.

La referencia a Maquiavelo no carece de sentido y quizá contribuya a situar el debate doctrinal, acotado por las circunstancias de la época de Richelieu, en un contexto más amplio. La razón "francesa" de Estado no surge por la importación intelectual de la "letra" del pensamiento del florentino, sino más bien por la adaptación de su "espíritu" al plano histórico concreto de un conflicto marcado por connotaciones muy precisas. Y, fundamentalmente, por la notable personalidad y ambición de una figura de la talla de Richelieu.

El enigmático Richelieu encarnaba de hecho para sus contemporáneos el tipo de político marcado por el maquiavelismo. [...] Fieles, si no a la letra, al menos al espíritu de la doctrina de Maquiavelo, hacen progresar al pensamiento político ya que, gracias a ellos, bajo el régimen de Richelieu, la corriente maquiavélica viene a fundirse con la de la Razón de Estado ${ }^{65}$.

Las peculiares circunstancias religiosas del conflicto entre la monarquía francesa y el Imperio Habsburgo ayudan a entender el surgimiento de este maquiavelismo "católico" en tierras galas y el alcance de las contradicciones que llevaba en su seno. Otro factor que no conviene olvidar, a la hora de interpretar el periodo y el precipitado histórico (esencialmente involuntario) que le sucedió, es la personificación existencial de dichas contradicciones. Con ello queremos decir que las indudables motivaciones políticas de sus principales artífices no se

63 Thuau, Raison d'État, 208.

64 Thuau, Raison d'État, 376-377.

65 Thuau, Raison d'État, 380. 
conjugaban con sus responsabilidades religiosas a costa de un tributo al cinismo o la hipocresía, tal y como cierta exposición deformada y caricaturesca ha pretendido subrayar más adelante, especialmente en el ámbito de la literatura ${ }^{66}$. El genuino talante religioso de hombres como Richelieu y el padre José, el más íntimo colaborador de la política del cardenal pero también un capuchino impregnado de ferviente ideal misionero ${ }^{67}$, no debe infravalorarse con criterios cronocéntricos si no se quiere desdibujar la significación real de los acontecimientos de la época. La sinceridad con la que estos ministros y religiosos vivieron sus propios conflictos interiores alimentó genuinamente el sentido de la política y el pensamiento de los principales protagonistas del momento, dejando un legado que influiría decisivamente en el porvenir de una nueva Europa.

Richelieu tal vez no tenía en su mesa su breviario y a Maquiavelo, pero su maquiavelismo era tan indiscutible como su fe. El padre José sueña con la Cruzada al mismo tiempo que trabaja para la ruina de la Monarquía muy Católica [...] El pensamiento de los estatistas, como el de los hombres del siglo XVII, une las contradicciones. Glorifica al príncipe, vice-rey de Dios, responsable ante su Creador y, al mismo tiempo, invoca la irresponsabilidad de la razón de Estado. [...] En buena lógica, las maneras de pensar que se oponen, en la vida se llaman y se completan. Las incoherencias también tienen su lógica. [...] Lo que nos parece incoherencia es, en una cierta medida, la marca misma de la vida. Esos principios aparentemente incompatibles que coexisten son en realidad el pasado y el presente que se afrontan ${ }^{68}$.

Aunque el sentido de la crítica a figuras como Richelieu suele insistir en el carácter amoral de sus empresas políticas y en la instrumentalización religiosa de sus intereses de poder, lo cierto es que muchos de los hombres que colaboraron con aquellas empresas fueron también movidos por un sincero deseo de purificación religiosa. La delimitación de los campos respectivos de la política y de la religión no solamente debía servir a liberar la política de servidumbres religiosas sino también, y por el mismo motivo, a emancipar la religión de ataduras políticas bastardas.

Más cercanos a la realidad, el estatismo de la época de Richelieu, asumiendo la violencia para superarla, intentó acordar la fuerza y la razón. Pretendiendo reconciliar la violencia y la razón, coqueteando con el maquiavelismo para superarlo, el estatismo propagó una nueva concepción de las relaciones de los

66 La principal responsabilidad, a este respecto, es la de Alejandro Dumas y sus tres mosqueteros.

67 La obra más representativa sobre la significación histórica de la figura del Padre José y su contribución a la carrera política de Richelieu sigue siendo la de Aldous Huxley. Aldous Huxley, Eminencia gris (Buenos Aires: Editorial sudamericana, 1945).

68 Thuau, Raison d'État, 391. 
hombres entre ellos y del hombre con Dios. Al laicizar el pensamiento político, desarrolla el derecho natural y una teología nueva. Los estatistas rechazan en primer lugar toda religión que mezcla demasiado a Dios con los asuntos humanos y que es predicada por gentes "más políticas y carnales que espirituales" como decía Theveneau. Juzgan muy sospechosas las empresas político-religiosas a la moda española, tales como la Liga, la Evangelización de las Indias, la guerra santa contra el hereje o el infiel. Aspiran a una religión más pura, más interior, desentendida de los intereses materiales y de las estrecheces del dogma ${ }^{69}$.

El realismo característico de este "maquiavelismo católico" pudo así concitar el apoyo de hombres sinceramente religiosos, sin los cuales difícilmente podría asimilarse la contemporaneidad de su emergencia con la aparición de figuras eminentemente espirituales como Pascal (1623-1662), y su decisiva y paralela contribución tanto al pensamiento científico como al pensamiento religioso. "La razón del siglo XVII es por tanto, en una cierta medida, hija del Estado de Richelieu", señala Etienne Thuau ${ }^{70}$. La laicización ambiental del espíritu de la época sin duda purificó el análisis político pero también engendró una nueva sensibilidad moral y religiosa, anunciando, por otro lado, los nuevos vientos ideológicos y culturales de la gran ruptura revolucionaria de finales del siglo XVIII.

Este estatismo cristiano concede una amplia confianza a la voluntad humana para edificar la sociedad civil. Se apoya sobre los racionalismos antiguos y modernos y reconoce una gran autonomía al Estado. [...] Sucede con las polémicas políticas con España lo mismo que con las polémicas de Pascal con los jesuitas: hicieron mucho para secularizar el pensamiento y expandir la moral y la política de los hombres honestos. Igualmente alejada de la teología españolizada como del ateísmo de Maquiavelo, la política de los hombres honestos $-\mathrm{O}$, más exactamente, la de los burgueses, los hombres de leyes y de los funcionarios- tiende a darse como fundamento el derecho natural, un racionalismo cristiano y, muy a menudo, el deísmo ${ }^{71}$.

69 Thuau, Raison d'Etat, 408.

70 Thuau, Raison d'État, 416. "La brutalidad de la época de Luis XIII hacía imposible los apriorismos políticos. [...] Pero este pensamiento opresivo es también un instrumento de liberación. En su aspecto positivo, las obras estatistas de nuestro periodo contribuyen a laicizar el Estado y la Sociedad de naciones, y el hecho más destacable de esta influencia es que el progreso del racionalismo es paralelo al del Estado" (Thuau, Raison d'État, 415).

71 Thuau, Raison d'État, 408. 
Relatar los nexos de este gran (y seguramente fundador) "momento maquiavélico francés"72 con la hecatombe revolucionaria, que se producirá siglo y medio después de la muerte de Richelieu, constituye la tarea de un trabajo que desborda los límites de este. Para rematarlo, nos contentaremos con apuntar, a modo de síntesis conclusiva, que la razón católica de Estado que se alza como principal novedad del pensamiento político francés en la época de Luis XIII, que en su reinado "permitió al gran Cardenal cumplir su incomparable dictadura fundadora y reparadora" $"$, es un ejemplo paradigmático de ese factor creativo que acompaña la historia del pensamiento occidental, en esa tensión permanente entre continuidad e innovación analizada por Sheldon Wolin, tal y como hemos destacado a lo largo de este breve estudio como apoyo hermenéutico de nuestra interpretación. Ese factor creativo está indudablemente vinculado a esa dimensión imaginativa inherente al pensamiento político, tal y como destaca el autor americano, pero también a las circunstancias socio-históricas que incardinan los saltos imaginativos del filósofo.

Las diversas concepciones del espacio indican que cada teórico ha visto el problema desde una perspectiva diferente, un ángulo particular de visión. De aquí se desprende que la filosofía política constituye una forma de "ver" los fenómenos políticos y que la forma en que se visualizarán los fenómenos depende en gran medida de la posición del observador ${ }^{74}$.

En otras palabras:

Los conceptos y categorías de una filosofía política se asemejan a una red que se lanza para capturar fenómenos políticos, que son luego extraídos y clasificados en una forma que parezca significativa y pertinente para el pensador particular. No obstante, en el procedimiento total, ha seleccionado una red particular y la ha arrojado en un lugar escogido ${ }^{75}$.

Aunque la época de Richelieu no contó con el sustento de una filosofía política similar a la de un observador de la guerra civil inglesa como Thomas Hobbes, sin embargo desarrolló un aparato propagandístico de autodefensa análogo, mutatis mutandis, al que conocimos en el siglo XX. Los intereses de la prensa cardenalista constituyen ese contexto socio-histórico al que hace referencia Wolin, y que ya no representa tanto la perspectiva adoptada por el "observador" (que se asocia a un agente imparcial y casi científico) sino el enfoque asumido por quien observa y al mismo tiempo incide en los acontecimientos, en una

72 Serge Audier, Machiavel, conflit et liberté (París: VRIN/EHESS, 2005).

73 Charles Maurras, Mis ideas políticas (Buenos Aires: Huemul, 1962), 288.

74 Wolin, Política y perspectiva, 39.

75 Wolin, Política y perspectiva, 43. 
posición similar a la que definió la trayectoria del Maquiavelo diplomático. "La filosofía política del régimen de Richelieu es por tanto menos el fruto de la reflexión desinteresada que de la máscara de la voluntad del Estado y un instrumento de dominación. La impresión de inacabamiento que ofrecen sus obras viene de sus aspiraciones prácticas", advierte también Thuau ${ }^{76}$. No es casualidad que este estudioso de la razón de Estado en la época de Richelieu destaque que "gracias a las deformaciones creativas y a las falsificaciones respetuosas, los juristas, los teólogos y los hombres de letras trabajaron para la 'cristalización estatista ${ }^{77}$. La referencia al factor creativo y a la posición fundamentalmente proactiva de sus nuevos intérpretes (observadores y actores al mismo tiempo) delimita claramente la peculiar dimensión socio-histórica del carácter imaginativo que podemos atribuir al pensamiento político que germinó al compás de la obra del cardenal. La fusión del jurista, teólogo y hombre de letras la representará, con un rol político similar, el intelectual del siglo $\mathrm{XX}^{78}$.

Los ecos de esta desacralización auspiciada por las exigencias propagandísticas del trono de Francia defendido por Richelieu se dejaron sentir, andando el tiempo, más allá de las coordenadas espacio-temporales del conflicto hispanofrancés que la vio nacer, atacando a los descendientes de Luis XIII con argumentos parecidos a los empleados por la publicística cardenalista. Solo dos siglos después, el argumento de la desacralización de la política que favorecía los intereses geopolíticos del reino de Francia terminó por arruinar sus propios cimientos interiores ${ }^{79}$.

Sin embargo, los antecedentes que culminaron en la Revolución Francesa se habían, entretanto, contaminado con la infección de un nuevo moralismo de matriz laica, un humanitarismo ilustrado que sin duda heredaba la desacralización trascendente del poder que se inició involuntariamente por iniciativa de la propaganda al servicio del cardenal, pero que reorientaba el potencial religioso de la tradición francesa hacia propósitos intramundanos. De ahí que debamos preguntarnos por la débil descendencia intelectual del crudo realismo político surgido en virtud de las demandas de afirmación de la monarquía francesa de Luis XIII.

Un rasgo de la propaganda cardenalista merece ser señalado: su tendencia a ofrecer una visión brutal de la realidad. [...] La prensa cardenalista tiende por tanto a presentar la vida política como una confrontación de fuerzas, óptica dura que parece para los "espíritus libres" un signo de verdad. Este rasgo de

\footnotetext{
76 Thuau, Raison d'État, 415.

77 Thuau, Raison d'État, 414.

78 Michel Winock, El siglo de los intelectuales (Madrid: Edhasa, 2010).

79 Dale Van Kley, Los orígenes religiosos de la Revolución Francesa (Madrid: Encuentro, 2003).
} 
la época de Richelieu choca si se compara sus producciones con las de una época ulterior ${ }^{80}$.

Tal vez la teoría francesa de la razón de Estado aparecida en la época de Richelieu murió como consecuencia de su éxito. El absolutismo francés iba a dominar la geopolítica europea a partir del tratado de Westfalia. Los requerimientos de su política, a partir de entonces, iban a ser diferentes a los impulsados bajo el mando del hombre de rojo. Si el maquiavelismo richeuliano debe considerarse con toda justicia una de las edades doradas del realismo político, se entiende mejor su naturaleza profunda si se lo considera, en el contexto europeo pre-westfaliano, como breve paréntesis entre el moralismo teológico que lo antecedió y el moralismo secular inmanentista que lo sepultó.

Nos podemos preguntar en efecto si la época de Richelieu, que hizo florecer el maquiavelismo, no fue el momento de verdad del siglo. En efecto, el siglo XVII, siglo de violencia, parece haber sido una "Belle époque" para el realismo político. [...] La Edad Media vivió en un mundo que se hacía soportable por la presencia de Dios. El siglo de las Luces, sin ignorar las miserias de la condición humana, alimenta un ideal humanitario. Nuestro sombrío periodo no mira sino los hechos brutos sin que ningún rayo de luz venga a iluminarlos ${ }^{81}$.

He aquí la paradoja que resume quizás la historia de la visión de lo político, que es también la historia de sus visionarios: que toda luz exterior a sus dominios no es una luz que ilumina sino una luz que ciega.

\section{REFERENCIAS BIBLIOGRÁFICAS}

Aron, Raymond. Memorias. Barcelona: RBA, 2013.

Audier, Serge. Machiavel, conflit et liberté. París: VRIN/EHESS, 2005.

Belloc, Hilaire. Richelieu. Barcelona: Editorial Juventud, 1937.

Burleigh, Michael. Causas sagradas. Madrid: Taurus, 2006.

Chauprade, Aymeric. Géopolitique. Constantes et changements dans l'histoire. París: Ellipses, 2007.

De Jouvenel, Bertrand. Sobre el Poder. Historia natural de su crecimiento. Madrid: Unión Editorial, 2011.

De Richelieu, Armand Jean du Plessis. Mémoires du Cardinal de Richelieu, sur le règne de Louis XIII: depuis 1610 jusqu'à 1638. Tome 1. Années 1610 à 1619. París: Foucault, 1823.

80 Thuau, Raison d'État, 415.

81 Thuau, Raison d'État, 380. 
Díez del Corral, Luis. Prólogo de La praxis política del absolutismo en el testamento político de Richelieu, por Graciela Soriano. Madrid: Centro de Estudios Constitucionales, 1979.

Erlanger, Philippe. Richelieu, París: Perrin, 2006.

Fayet, Benjamin. "Kiel et Tanger de Charles Maurras: essai géostratégique visionnaire et source intellectuelle de la Vème République", Philitt, 19 de noviembre de 2014. Consultado el 8 de marzo de 2020. https://goo.gl/MwcXQ3.

Forte, Juan Manuel y Pablo López. Introducción de Maquiavelo y España. Maquiavelismo y antimaquiavelismo en la cultura española de los siglos XVI y XVII. Madrid: Biblioteca Nueva, 2008).

Freund, Julien. La esencia de lo político. Madrid: Centro de Estudios Políticos y Constitucionales, 2018.

Gauchet, Marcel. El desencantamiento del mundo. Una historia política de la religión. Madrid: Trotta, 2005.

Gómez Dávila, Nicolás. Escolios a un texto implícito, Bogotá: Villegas Editores, 2001. Huguenin, François. Les grandes figures catholiques de France. París: Perrin, 2016. Huxley, Aldous. Eminencia gris. Buenos Aires: Editorial sudamericana, 1945.

Maurras, Charles. Mis ideas políticas. Buenos Aires: Huemul, 1962.

Negro, Dalmacio. Gobierno y Estado. Madrid: Marcial Pons, 2002.

Negro Dalmacio. Sobre el Estado en España. Madrid: Marcial Pons, 2007. Negro, Dalmacio. Lo que Europa debe al cristianismo. Madrid: Unión Editorial, 2007.

Negro, Dalmacio. Historia de las formas del Estado. Una introducción. Madrid: El Buey Mudo, 2010.

Thuau, Etienne. Raison d'État et pensée politique à l'époque de Richelieu. París: Albin Michel, 2000.

Van Kley, Dale. Los orígenes religiosos de la Revolución Francesa. Madrid: Encuentro, 2003.

Winock, Michel. El siglo de los intelectuales. Madrid: Edhasa, 2010.

Wolin, Sheldon. Política y perspectiva. Continuidad e innovación en el pensamiento político occidental. México DF: Fondo de Cultura Económica, 2012.

Zarka, Yves-Charles. Raison et déraison d'État. París : PUF, 1994.

Domingo González Hernández

Facultad de Trabajo social

Universidad de Murcia

Campus Universitario de Espinardo

30100 Murcia (España)

https://orcid.org/0000-0003-3344-230X 